\title{
Clonidine-induced cardiovascular effects after stereotaxic application in the hypothalamus of rats
}

Clonidine, a closely related analogue of the sympathomimetic imidazolines reduces heart rate and lowers blood pressure in animals as well as in patients with hypertension (Hoefke \& Kobinger, 1966; Michel, Zimmerman \& others, 1966). There is evidence that clonidine acts in the central nervous system (Sherman, Greca \& others, 1968; Shaw, Hunyor \& Korner, 1971) by activation of noradrenaline receptors (Schmitt \& Schmitt, 1969, 1970; Kobinger \& Walland, 1971).

Although the findings indicate a central site of action in bulbar or diencephalic structures (Schmitt \& Schmitt, 1969; Shaw \& others, 1971), clonidine has not been studied after intracerebral application.

We have injected clonidine via stereotaxically implanted cannulas directly into various areas of the hypothalamus in anaesthesized rats while blood pressure and heart rate were recorded simultaneously on a Grass polygraph. Most of the injections were made $2.5-3.5 \mathrm{~mm}$ anterior and $2.4-2.8 \mathrm{~mm}$ below the interaural line and $0.5-0.7 \mathrm{~mm}$ lateral acording to the atlas of König \& Klippel (1963). Details of the experimental procedure will be published elsewhere.

Table 1. Mean effects and s.e. of $1 \mu$ l amounts of solutions of clonidine injected directly into the hypothalamus of rats on systolic blood pressure and heart rate.

\begin{tabular}{|c|c|c|c|c|c|}
\hline \multirow{2}{*}{ 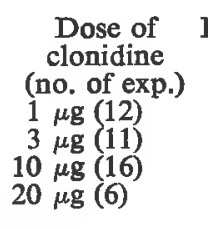 } & \multirow{2}{*}{$\begin{array}{c}\text { B.p. just before } \\
\text { injection } \\
\text { (mm Hg) } \\
135 \\
138 \\
142 \\
140\end{array}$} & \multicolumn{4}{|c|}{ Blood pressure fall (mg $\mathrm{Hg}$ ) at various times after injection } \\
\hline & & $\begin{array}{l}1 \mathrm{~min} \\
6 \pm 0.6^{* *} \\
6 \pm 0.6^{*}\end{array}$ & $\begin{array}{c}5 \mathrm{~min} \\
-0.8 \pm 1.6 \\
-4.4 \pm 1.7^{*} \\
-19.4 \pm 2.4^{* *} \\
-21.5 \pm 2.9^{* *}\end{array}$ & $\begin{array}{c}15 \mathrm{~min} \\
-0.4 \pm 2 \cdot 7 \\
=8.8 \pm 3 \cdot 0^{*} \\
-33.3 \pm 5.5^{* *} \\
-34.2 \pm 5.6^{* *}\end{array}$ & $\begin{array}{c}30 \mathrm{~min} \\
-8 \cdot 9 \pm 4 \cdot 1^{*} \\
-38 \cdot 6 \pm 6 \cdot 2^{* *} \\
-40 \cdot 4 \pm 7 \cdot 9^{* *}\end{array}$ \\
\hline \multirow{2}{*}{$\begin{array}{c}\text { Dose } \\
\text { (no. of exp.) }\end{array}$} & \multirow{2}{*}{$\begin{array}{l}\text { Heart rate } \\
\text { just before } \\
\text { injection }\end{array}$} & \multicolumn{4}{|c|}{ Reduction of the heart rate (beats/min) } \\
\hline & & $1 \mathrm{~min}$ & 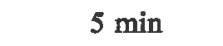 & 15 & \\
\hline $\begin{aligned} 1 \mu \mathrm{g}(12) \\
3 \mu \mathrm{g}(11) \\
10 \mu \mathrm{g}(15) \\
20 \mu \mathrm{g}(6)\end{aligned}$ & $\begin{array}{l}416 \\
406 \\
416 \\
423\end{array}$ & $\begin{array}{l}-23 \cdot 7 \pm 3 \cdot 0^{* *} \\
-12 \cdot 5 \pm 5 \cdot 6^{*}\end{array}$ & $\begin{array}{l}-12.5 \pm 6.3 \\
-19.5 \pm 6.5^{*} \\
-69.3 \pm 9.3^{* *} \\
-56.8 \pm 10.4^{* *}\end{array}$ & $\begin{array}{l}-15 \cdot 0 \pm 8 \cdot 4 \\
-25 \cdot 9 \pm 8 \cdot 4^{*} \\
-75 \cdot 0 \pm 12 \cdot 6 * \\
-103 \cdot 3 \pm 12 \cdot 9^{* *}\end{array}$ & $\begin{array}{l}-22 \cdot 7 \pm 9.3^{*} \\
-72 \cdot 4 \pm 14 \cdot 3^{* *} \\
-109 \cdot 6 \pm 6.4\end{array}$ \\
\hline$*=P<$ & \multicolumn{2}{|c|}{$* *=P<0-001$} & & & \\
\hline
\end{tabular}

From the results in Table 1, it is evident that a dose of $10 \mu \mathrm{g}$ clonidine intrahypothalamically induces a strong reduction in heart rate and a lowering of the blood pressure. The effects of $3 \mu \mathrm{g}$ are clear in most rats while $1 \mu \mathrm{g}$ still induces a reduction in heart rate in most experiments, but the effect on blood pressure is negligible. At $10 \mu \mathrm{g}$ the heart rate was reduced for about $1 \mathrm{~h}$ while blood pressure was lowered for about $2 \mathrm{~h}$. These changes were reversible.

The strongest effects of clonidine were found more lateral than medial in the far posterior hypothalamus at the level of fasciculus mamillotegmentalis and the decussatio supramamillaris (Fig. 1).

Noradrenergic nerve terminals have been found in those sites in the hypothalmus where clonidine exerts its strongest cardiovascular effects (Dahlström \& Fuxe, 1965) 


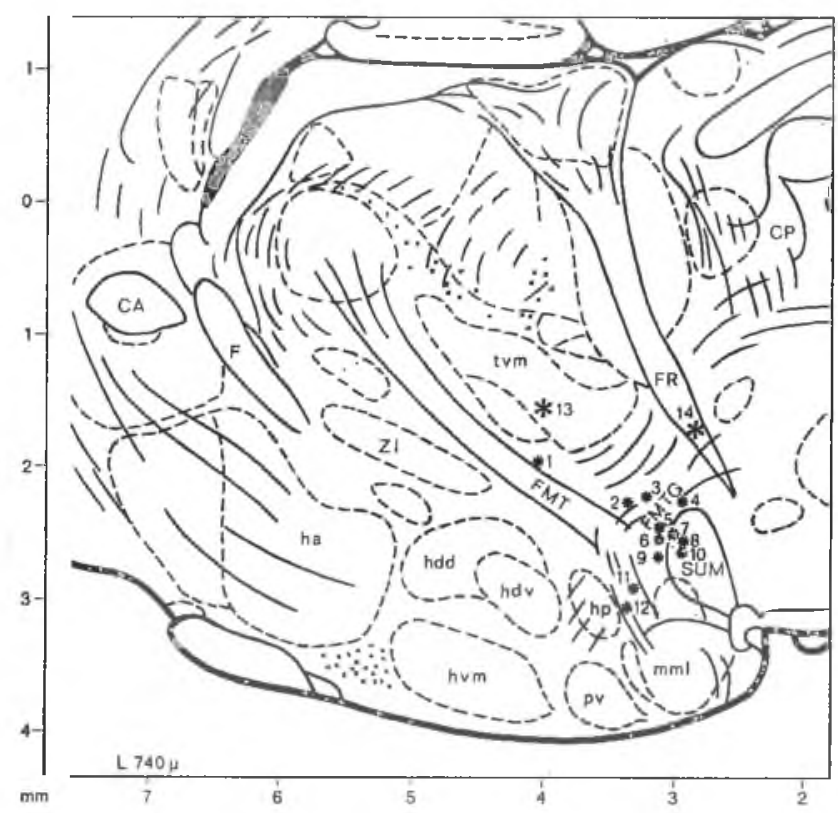

Fig. 1. Saggital section through the hypothalamus of a rat with indications of the sites of injection. At the sites 2-13 clonidine causes both a reduction in heart rate and a fall in blood pressure. At 1 only a blood pressure fall was observed while at 13 and 14 no effect could be obtained or cardiovascular changes occurred after a latency of more than $30 \mathrm{~min}$.

in agreement with an action of clonidine on adrenergic structures in the posterior hypothalmus.

Recent studies indicate that the antihypertensive drug methyldopa induces hypotensive effects by means of an action on the central nervous system of its metabolite $\alpha$-methylnoradrenaline (Henning \& Rubenson, 1971). Methyldopa and also the monoamine oxidase inhibitor pargyline may exert its hypotensive effects via noradrenaline receptors in the hypothalamus.

Department of Pharmacology, Catholic University Medical School, Geert Grooteplein 21 noord, Nijmegen, The Netherlands.

February 29, 1972

\section{H. A. J. STRUYKER BOUdIER J. M. VAN ROSSUM}

\section{REFERENCES}

Dahiström, A. \& FuXE, K. (1965). Acta physiol. scand., 64, Suppl. 247.

Henning, M. \& Rubenson, A. (1971). J. Pharm. Pharmac., 23, 407-411.

HOEFKE, W. \& KoBINGER, W. (1966). Arzneimittel-Forsch., 16, 1038-1050.

Kobinger, W. \& Walland, A. (1971). Europ. J. Pharmac., 16, 120-122.

KöNIG, J. F. R. \& KLIPPEL, R. A. (1963). The rat brain. Baltimore: Williams and Wilkins.

Michel, D., Zimmerman, W., Nessehr, A. \& Seraphim, P. (1966). Dt. med. Wschr., 91, 15401547 .

Shaw, J., Hunyor, F. \& Korner, P. I. (1971). Europ. J. Pharmac., 15, 66-78.

SheRMAN, G. F., GreCA, G. I., WOODS, R. J., \& BUCKLEY, J. R. (1968). Ibid., 2, 326-328.

SснмтT, H. \& SснмтT, H. (1969). Ibid., 6, 8-12.

Sснмітт, H. \& Sснмтт, H. (1970). Ibid., 9, 7-13. 